
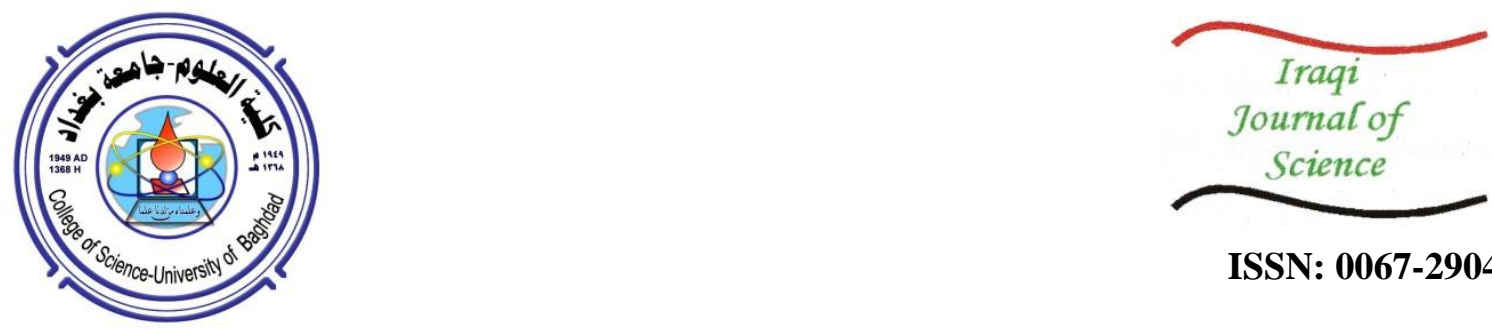

ISSN: 0067-2904

\title{
Determination of Magnitudes and Orientation of the Paleostress of Bekhme Structure in Shaqlawa area, Northerneastern Iraq
}

\author{
Atheer E. K. AL- Hachem* , Shatha Hassan \\ Department of Geology, College of Science, University of Baghdad, Baghdad, Iraq
}

Received: $12 / 3 / 2020$

Accepted: 20/10/2020

\begin{abstract}
This study presents the determination of the paleostress magnitudes and orientation of Bekhme Structure in Shaqlawa area, northeastern Iraq. Paleostress analysis of slip-fault measurements is performed using Right dihedral, Lisle diagram, and Mohr Circles methods. Depending on Mohr Circles, Bott law, and vertical thickness, the magnitudes of the paleostress at the time of the tectonic activity were determined. Firstly, Georient Software was used to estimate the orientation of the paleostresses $(\sigma 1, \sigma 2$, and $\sigma 3)$. Secondly, using the rupture friction law, taking into account the depth of the overburden and the vertical stress $(\sigma v)$,the magnitudes of the paleostresses were calculated $(\sigma 1=4500$ bars, $\sigma 2=1900$ bars and $\sigma 3=700$ bars). The high magnitudes of the principal stress axes may be attributed to the active tectonic events which led to the deformation of the area during the Cretaceous and Tertiary periods. The study area shows that the poles of the measured faults lie in the reactivated area of Mohr circles. This indicates the instability of the study area. The study area is estimated to have high importance, due to the possibility of the existence of deposited hydrocarbons. Fold- Thrust belt marks the deformation fronts of the major orogeny that forms from the collision of the Arabian Plate with the Turkish and Iranian Plates.
\end{abstract}

Keywords: Paleostress Analysis, Mohr Circles, Shaqlawa, Iraq.

\section{تحديد اتجاه وقيم الاجهاد القديم لتركيب بخمة في منطقة شقلاوة شمال شرق العرلق}

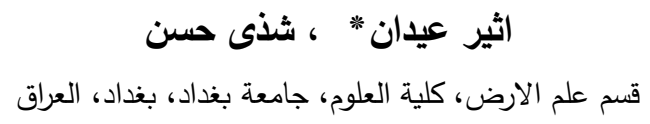

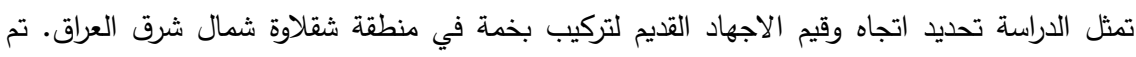

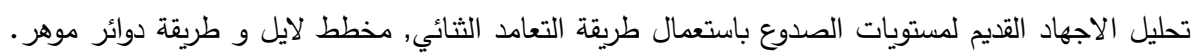

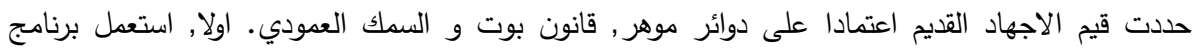

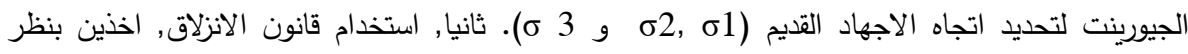

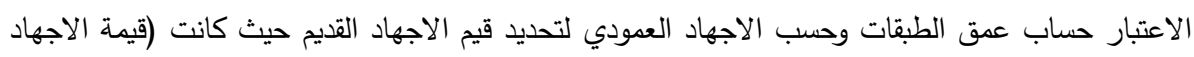

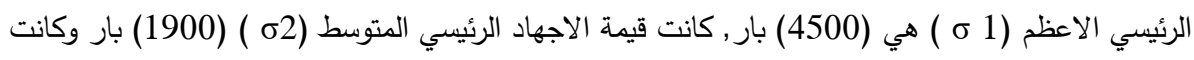

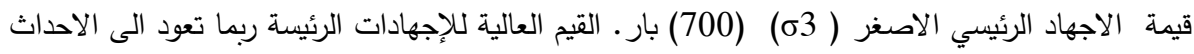

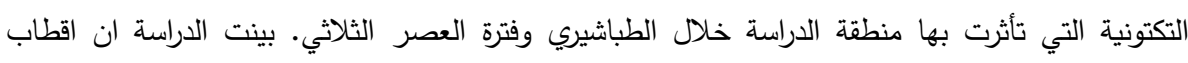

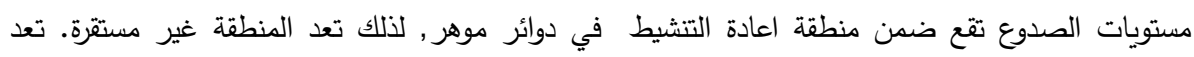

*Email: atheergeo1980@ scbaghdad.edu.iq 


$$
\text { منطقة الدراسة مهمة لتواجد المواد الهيدروكربونية ضمن نطاق الصدوع الزاحفة نتيجة التشوه الحاصل بتصادم }
$$

\section{Introduction}

$$
\text { الصفيحة العربية بالصفيحتين التركية والايرانية. }
$$

Behkme Structure lies in Shaqlawa area, northeastern Iraq. It runs along NW-SE trend, with a symmetrical anticline, where the southwestern limb is steeper than northeastern limb, with doubly plunging anticline. The southeastern plunge is affected by strike slip faults and the northwestern plunge is an en-echelon of Aqra Structure that is separated by thrust fault, extending parallel to Zagros Belt and located within the High Folded Zone in the Unstable Shelf of Iraq. The length of the structure is about (30) $\mathrm{Km}$ and the width is about (5) $\mathrm{Km}$. It is located between latitudes $\left(36^{\circ} 37^{\prime}-36^{\circ} 48^{\prime}\right.$ North) and longitudes $\left(44^{\circ} 00^{\prime}-44^{\circ} 23^{\prime}\right.$ East), as illustrated in Figure-1. There are many structural studies which have been carried out on the High Folded Zone of Iraq and dealt with the orientation and magnitude of the paleostresses [1-6]. Generally, the state of paleostress in the rocks is anisotropic and is defined by stress ellipsoid axes, which characterizes the magnitudes of the principal stresses [7,8]. Most authors who are concerned with fault slip data aim to determine the principal stresses orientation. However, the main aim of the present study is to determine the structural model of the paleostress (orientations, magnitudes, and stress Ratio) and understand the dynamics of the study area.

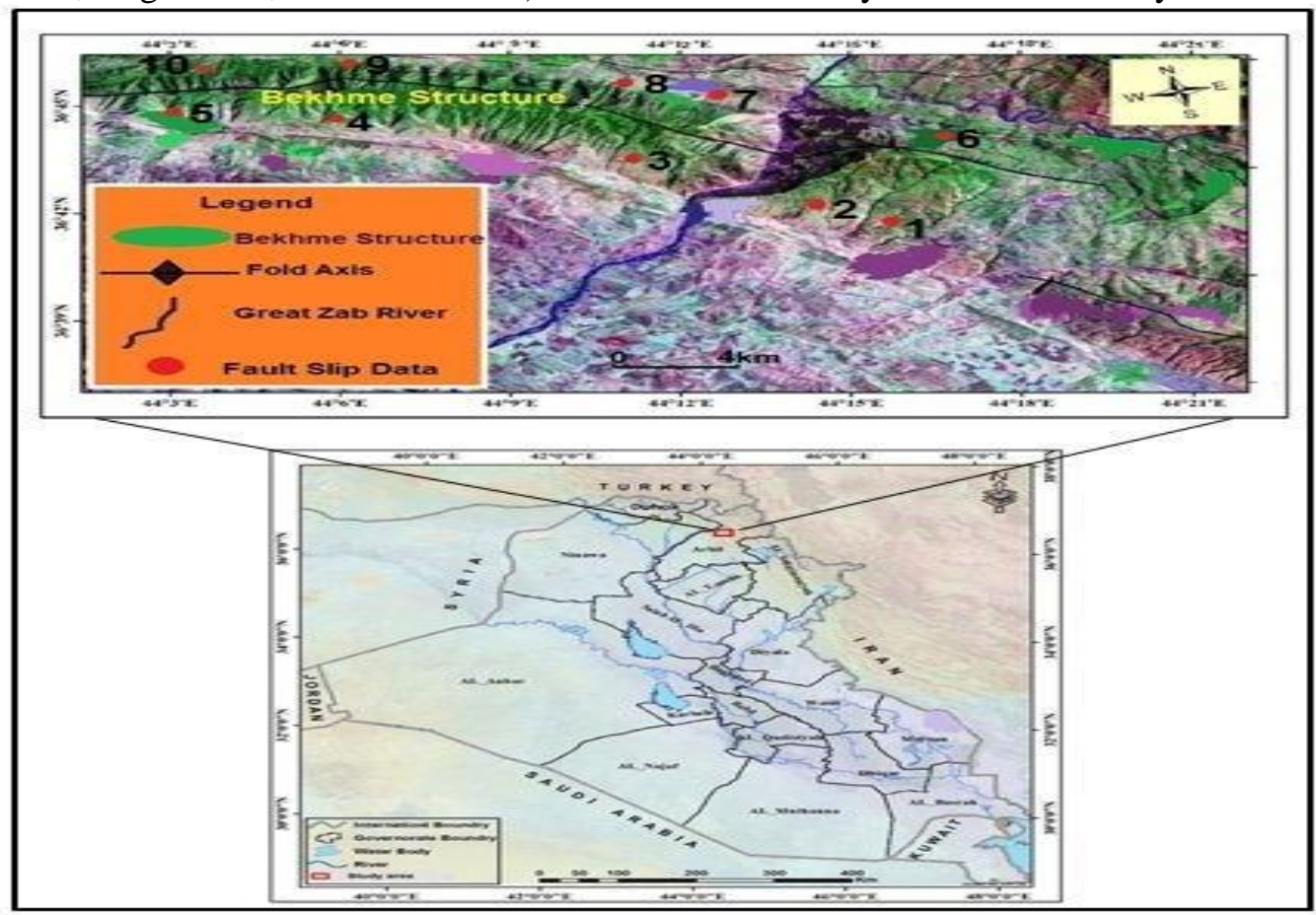

Figure 1- Satellite image showing the study area [9]

\section{Geological Setting}

The study area belongs to the unstable shelf represented by the High Folded Zone [10, 11]. Bekhme Structure exposes a large number of lithostratigraphical divisions. The exposed formations range in age from Late Jurassic (Sargalu Formation) to Late Pliocene (Bai-Hassan Formation). These formations were ordered, from the oldest to the youngest as: Sargalu, Naokelekan, Barsarin, and Chia Gara Formations [12]. The age of these formations ranges from Late Jurassic to Early Cretaceous. They comprise well bedded limestone and marly limestone, which contain a large number of Ammonite Fossils. The thickness of these formations is about (150) $\mathrm{m}$.

Balambo- Sarmord Formation has an age of Early Cretaceous. It consists of dolomitic limestone and marly limestone. The thickness of the formation is about (80) $\mathrm{m}$. Qamchuqa Formation belongs to the Early Cretaceous age. It consists of brown, hard, and bedded to massive limestone and dolomite. The thickness of the formation is about (635) m. Akra- Bekhme Formation belongs to the Late Cretaceous. It consists of limestone and dolomite. The thickness of the formation is about (400) $\mathrm{m}$. Shiranish Formation belongs to the Late Cretaceous. It comprises thinly well bedded marly and chalky limestone. Limestone of this formation is hard jointed and fractured. The thickness of the 
formation is (100) $\mathrm{m}$. Tanjero Formation belongs to the Late Cretaceous. It consists of shale, sandstone, siltstone, and claystone. The thickness of the formation is (200) m. Kolosh Formation belongs to the Paleocene- Early Eocene. It consists of fine clastic sandstone, siltstone, and claystone. The thickness of the formation is (140) m. Khurmala Formation belongs to the Middle Eocene. It consists of red claystone and siltstone along with few sandstone and conglomerate. The thickness of the formation is (60) m. Gercus Formation belongs to the Middle Eocene. It consists of red claystone, red siltstone, and sandstone. The thickness of the formation is (95) m. Pila Spi Formation belongs to the Middle- Late Eocene. It comprises limestone and dolomite and marly limestone. The thickness of the formation is (90) m. Fat'ha Formation belongs to the Middle Miocene. It consists of claystone and marls with alternations of thick limestone. The thickness of the formation is (180) $\mathrm{m}$. Injana Formation belongs to the Late Miocene. It comprises thin bedded sandstone, siltstone, marls, and reddish brown and brownish grey claystone. The thickness of the formation is (250) m. Muqdadiya Formation belongs to the Early Pliocene. It consists of sandstone and pebbles that increase in size upward. The thickness of the formation is (230) m. Bai-Hassan Formation belongs to the Late Pliocene. It comprises conglomerate and claystone with some siltstone and sandstone beds. The thickness of the formation is $(650) \mathrm{m}$.

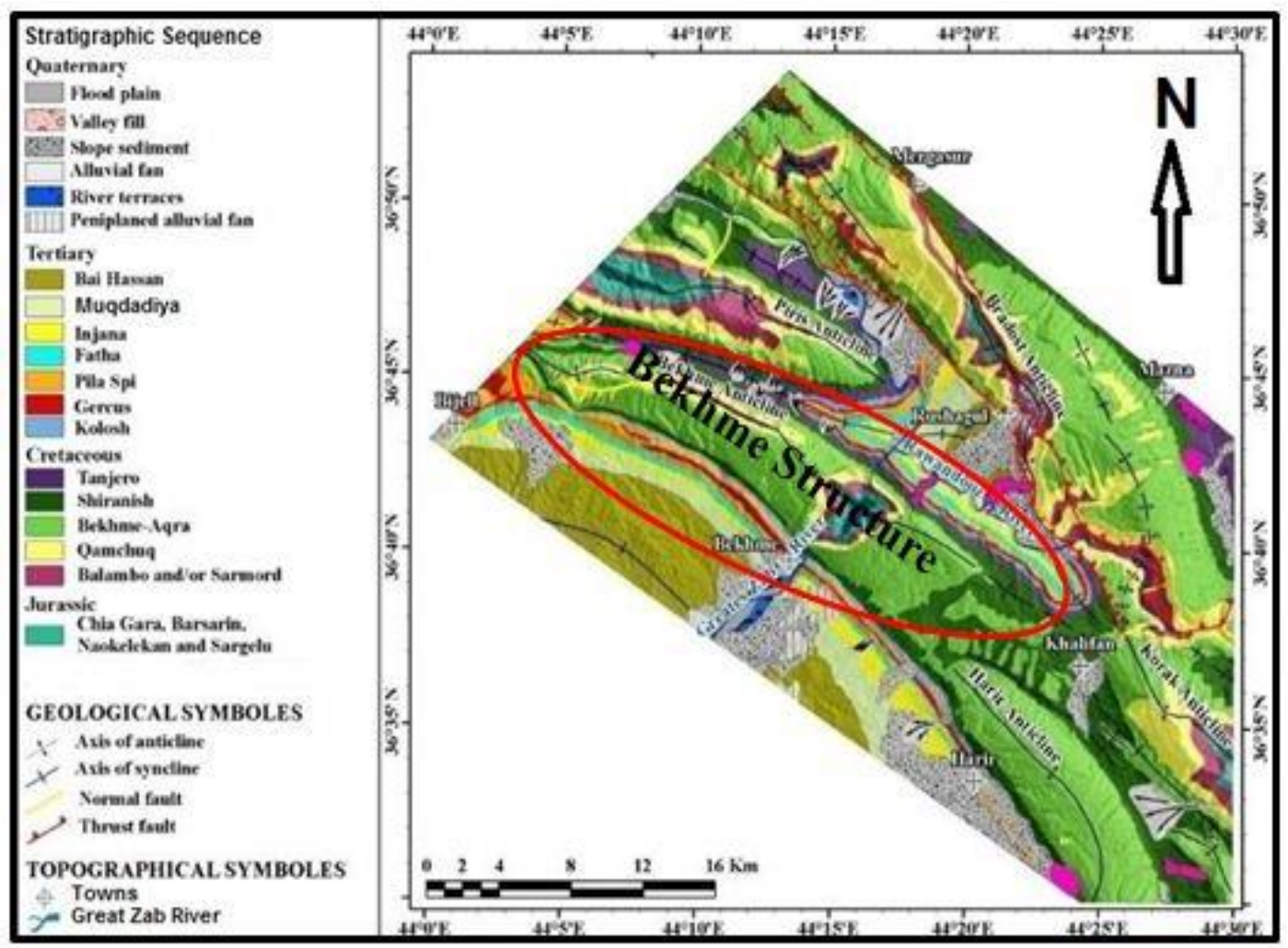

Figure 2- Geological map of the study area, modified after Shihab, 2015 [13].

\section{Methodology}

\section{1: Faults Orientation Determination Using Right Dihedral Method}

Several authors $[2,3,4,5,14,15]$ used the fault slip data to calculate directions of the paleostress field.

Right dihedral method was used to determine the trend of principal stresses axes $(\sigma 1, \sigma 2$, and $\sigma 3)$ of the studied area, as follows. The maximum principal stress $(\sigma 1)$ and intermediate principal stress $(\sigma 2)$ were horizontal and the minimum principal stress $(\sigma 3)$ was sub-vertical. The dip of these faults was to the north east and south west directions in all fields of the study area (Plates -1 and 2; Figure-3). The determination of the principal stress axis orientations was performed according to an earlier study [16]. 


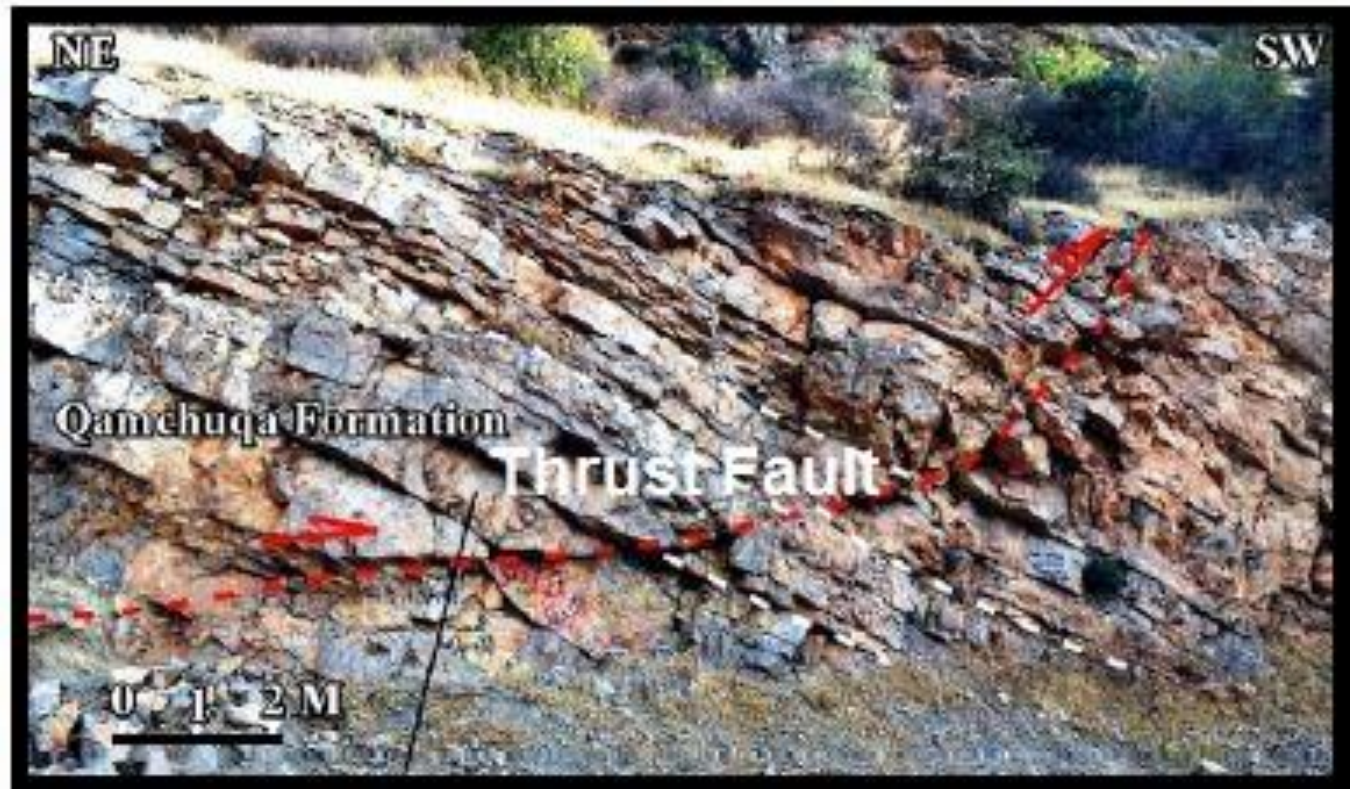

Plate 1- Thrust Fault in Qamchuqa Formation in the SW limb of Bekhme Structure in the study area.

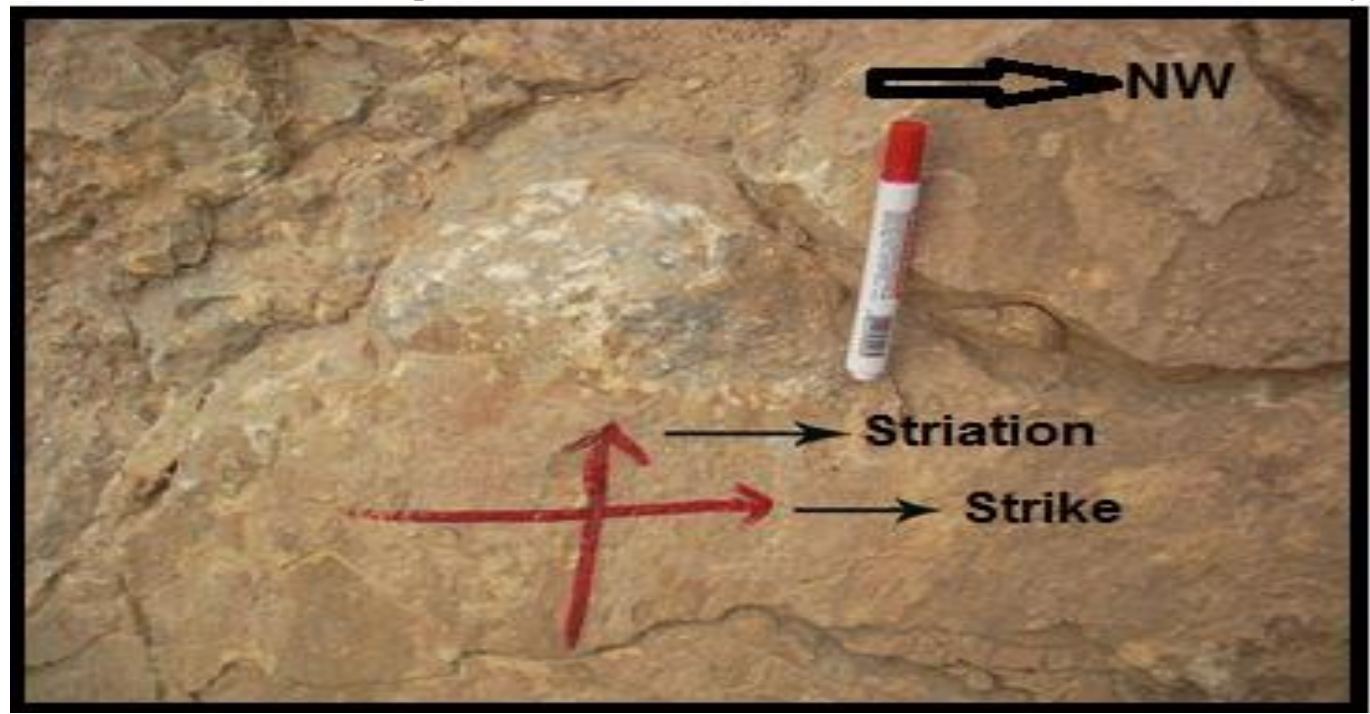

Plate 2- Striation on the fault plane of Bekhme Structure in the study area.

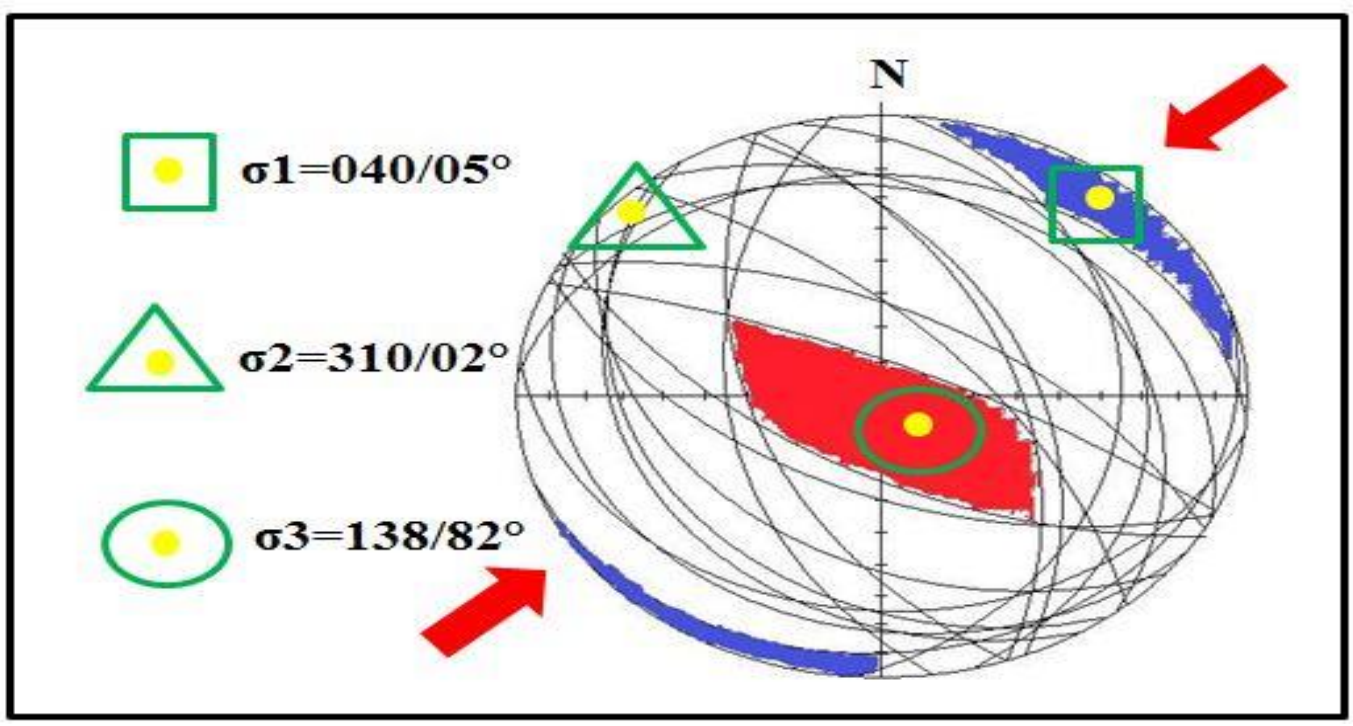

Figure 3- Right dihedral method showing the distribution orientation of principal stress axes in the study area. 


\section{2: Determination of the Paleostress Magnitudes Using Mohr Circles}

The magnitude of the vertical stress ( $\sigma \mathrm{v})$ can be determined through estimating the lithostatic load and one of the principal stress axes. At the time of the tectonic event, the depth can be determined, as well as the average density of the overlying rocks. Additional information on the value of one principal stress can be obtained using the following equation [17, 18, 19]:

The vertical stress $\sigma \mathrm{v}=\rho \mathrm{gz}$

where:

$\rho:$ is the crustal density $\left(\mathrm{kg} / \mathrm{m}^{3}\right)$.

$\mathrm{g}$ : is the acceleration of gravity $\left(\mathrm{m} / \mathrm{s}^{2}\right)$.

$\mathrm{z}$ : is the paleodepth (m).

Mohr circles and Lisle diagram were used to represent the state of stress (Figure - 4). Mohr Plotter Software was used to determine paleostress magnitudes. The angles $(\alpha, \beta, \gamma)$ were measured between the perpendicular plane $(\mathrm{N})$ on the fault plane and the direction of the principal stress axes $(\sigma 1, \sigma 2$, and $\sigma 3)$, respectively, of all faults. To determine stress ratio (R) value of all faults, Bott equation was applied [20].

$\mathrm{R}=\tan \theta \operatorname{Im}-\mathrm{I}^{2} \mathrm{n} / \mathrm{n}-\mathrm{n}^{3}$

where:

$\mathrm{R}$ : is the ratio of the principal stress.

$\theta$ : is the pitch angle.

(I, $\mathrm{m}, \mathrm{n})$ : are cosine values of the angles $(\alpha, \beta, \gamma)$, respectively, as shown in Table -1 .

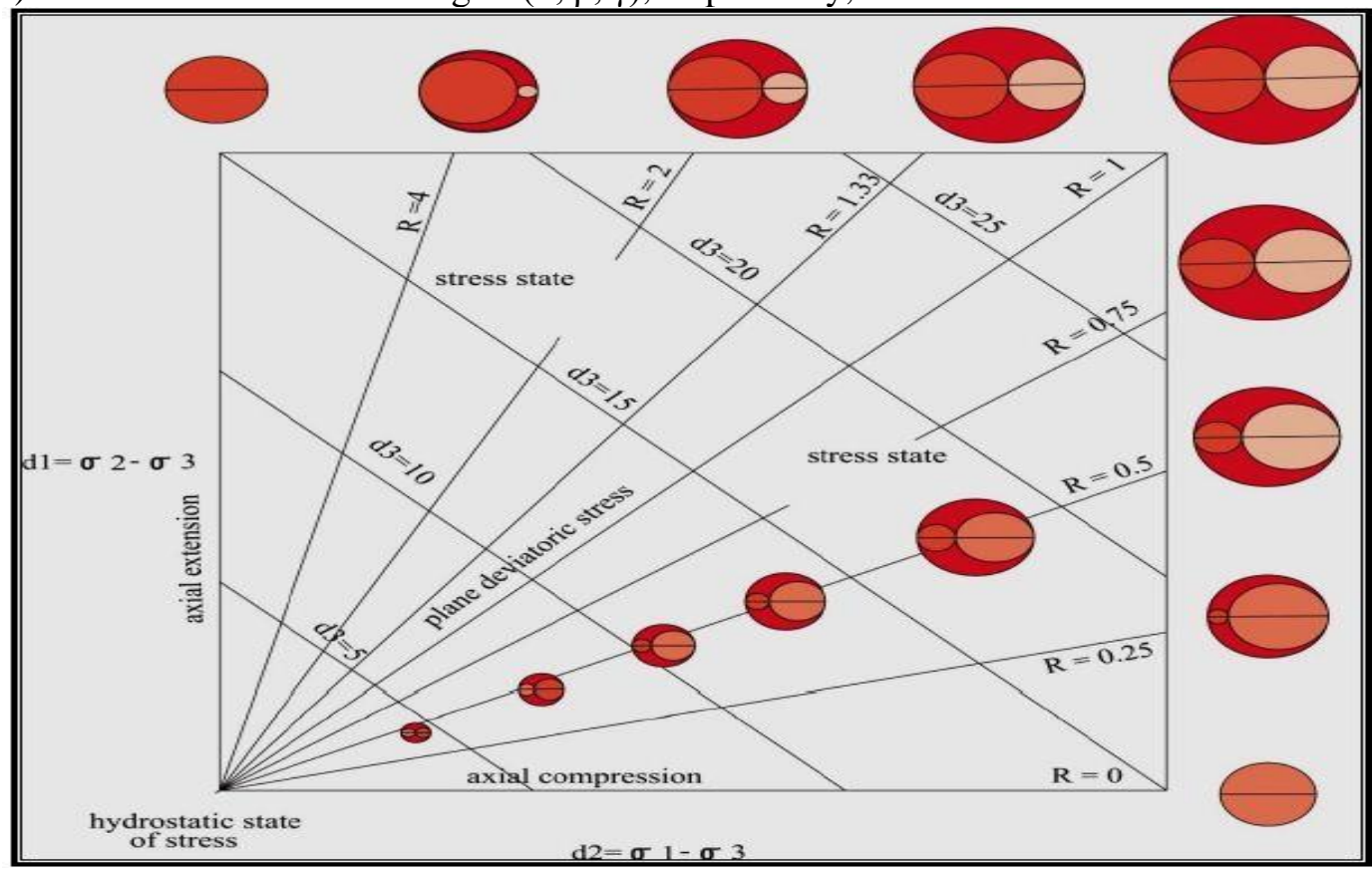

Figure 4- Lisle diagram of the stress states representation [21].

Table 1- The magnitudes of the stress ratios (R) for faults in the study area.

\begin{tabular}{|c|c|c|c|c|c|c|c|}
\hline NO. & $\begin{array}{c}\text { Fault plane } \\
\text { D.D/D.A }\end{array}$ & $\begin{array}{l}\text { Pitch } \\
\text { (ө) }\end{array}$ & $\operatorname{Tan}(\theta)$ & $(\alpha)$ & $(\beta)$ & (y) & $\begin{array}{c}\mathrm{R}=\tan \theta \operatorname{Im}-I^{2} n / n- \\
n^{3}\end{array}$ \\
\hline 1 & $048 / 70^{\circ}$ & $82^{\circ} \mathrm{NW}$ & $7.11^{\circ}$ & $60^{\circ}$ & $84^{\circ}$ & $36^{\circ}$ & 0.5 \\
\hline 2 & $028 / 65^{\circ}$ & $80^{\circ} \mathrm{SE}$ & $5.67^{\circ}$ & $66^{\circ}$ & $84^{\circ}$ & $30^{\circ}$ & 0.3 \\
\hline 3 & $024 / 80^{\circ}$ & $72^{\circ} \mathrm{SE}$ & $3.07^{\circ}$ & $35^{\circ}$ & $82^{\circ}$ & $63^{\circ}$ & 0.08 \\
\hline 4 & $067 / 56^{\circ}$ & $82^{\circ} \mathrm{NW}$ & $7.11^{\circ}$ & $62^{\circ}$ & $81^{\circ}$ & $37^{\circ}$ & 0.8 \\
\hline 5 & $070 / 60^{\circ}$ & $81^{\circ} \mathrm{NW}$ & $6.31^{\circ}$ & $79^{\circ}$ & $80^{\circ}$ & $21^{\circ}$ & 1.3 \\
\hline 6 & $205 / 62^{\circ}$ & $82^{\circ} \mathrm{SE}$ & $7.11^{\circ}$ & $81^{\circ}$ & $82^{\circ}$ & $17^{\circ}$ & 1 \\
\hline
\end{tabular}




\begin{tabular}{|c|c|c|c|c|c|c|c|}
\hline 7 & $210 / 68^{\circ}$ & $79^{\circ} \mathrm{SE}$ & $5.14^{\circ}$ & $\mathbf{6 2}^{\circ}$ & $\mathbf{8 2}^{\circ}$ & $\mathbf{3 6}^{\circ}$ & $\mathbf{0 . 4}$ \\
\hline 8 & $250 / 61^{\circ}$ & $\mathbf{8 0}^{\circ} \mathrm{NW}$ & $\mathbf{5 . 6 7}^{\circ}$ & $\mathbf{6 7}^{\circ}$ & $\mathbf{8 5}^{\circ}$ & $\mathbf{2 8}^{\circ}$ & $\mathbf{0 . 2}$ \\
\hline 9 & $262 / 55^{\circ}$ & $77^{\circ} \mathrm{NW}$ & $\mathbf{4 . 3 3}^{\circ}$ & $\mathbf{8 2}^{\circ}$ & $\mathbf{6 5}^{\circ}$ & $\mathbf{3 3}^{\circ}$ & $\mathbf{0 . 8}$ \\
\hline 10 & $219 / 44^{\circ}$ & $\mathbf{7 5}^{\circ} \mathrm{NW}$ & $\mathbf{3 . 7 3}^{\circ}$ & $\mathbf{3 1}^{\circ}$ & $\mathbf{8 3}^{\circ}$ & $\mathbf{6 6}^{\circ}$ & $\mathbf{0 . 2}$ \\
\hline
\end{tabular}

\section{Results}

Many authors studied cohesion strength of the sedimentary rocks and they showed that the range of the cohesion strength magnitudes is between zero (0) bars (the rock is broken), with no stick between the two blocks of faults, and (100) bars [1], [2], [3], [4], [5], [14], [15], [22], [23], [24] and [25]. According to the compilations used by several authors, the internal friction angle $(\phi)$ for the sedimentary rocks is $\left(45^{\circ}\right)$ [1], [2], [3], [4], [5], [14] and [15]. Under the above determination, which is based on rupture friction analysis that depends on the stress ratio, the sliding friction angles and the vertical stress have directly resulted in the measurements of the magnitudes of the paleostresses. Two friction sliding line angles of thrust faults were measured experimentally in this study for fault surfaces. These measures showed values of angles where the average of the minimum friction sliding line angle was $\left(25^{\circ}\right)$ from the origin of the smooth fault surfaces as limestone rocks, whereas the average of the maximum friction sliding line angle was $\left(35^{\circ}\right)$ of rough fault surfaces as sandstone rocks.

Thrust faults measurements were obtained from two limbs of Bekhme Structure of the study area. The depth of the rocks was measured at the field and found to be equal to $(3110 \mathrm{~m})$. The acceleration of gravity $(\mathrm{g})$ was equal to $\left(9.8 \mathrm{~m} / \mathrm{s}^{2}\right)$, whereas the average density of the sedimentary rock was estimated to be (2300) $\mathrm{kgm} / \mathrm{m}^{3}$. Therefore, the vertical stress could be estimated to be $(\sigma \mathrm{v}=\sigma 3)$.

Mohr circles were drawn depending on the stress ratio $(\mathrm{R})$ magnitude $(\mathrm{R}=0.5)$ and the points (poles of the faults) were plotted depending on the angles $(\alpha, \beta, \gamma)$ on these circles. The plot poles in Mohr diagram should be found above the sliding line and beneath the failure envelope. The results obtained by the application of this method are summarized in Figure-5 and Table -2 .

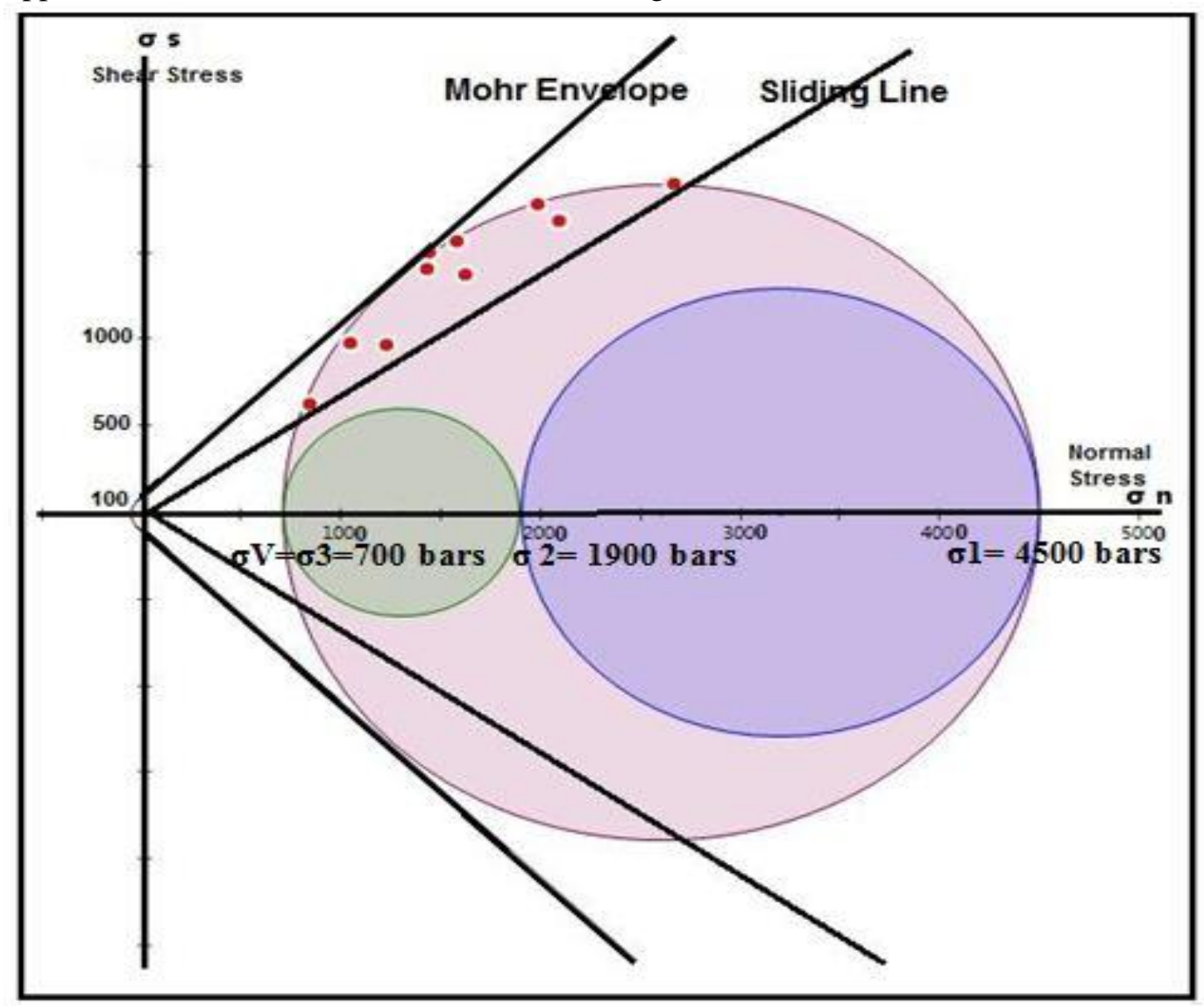

(a) 


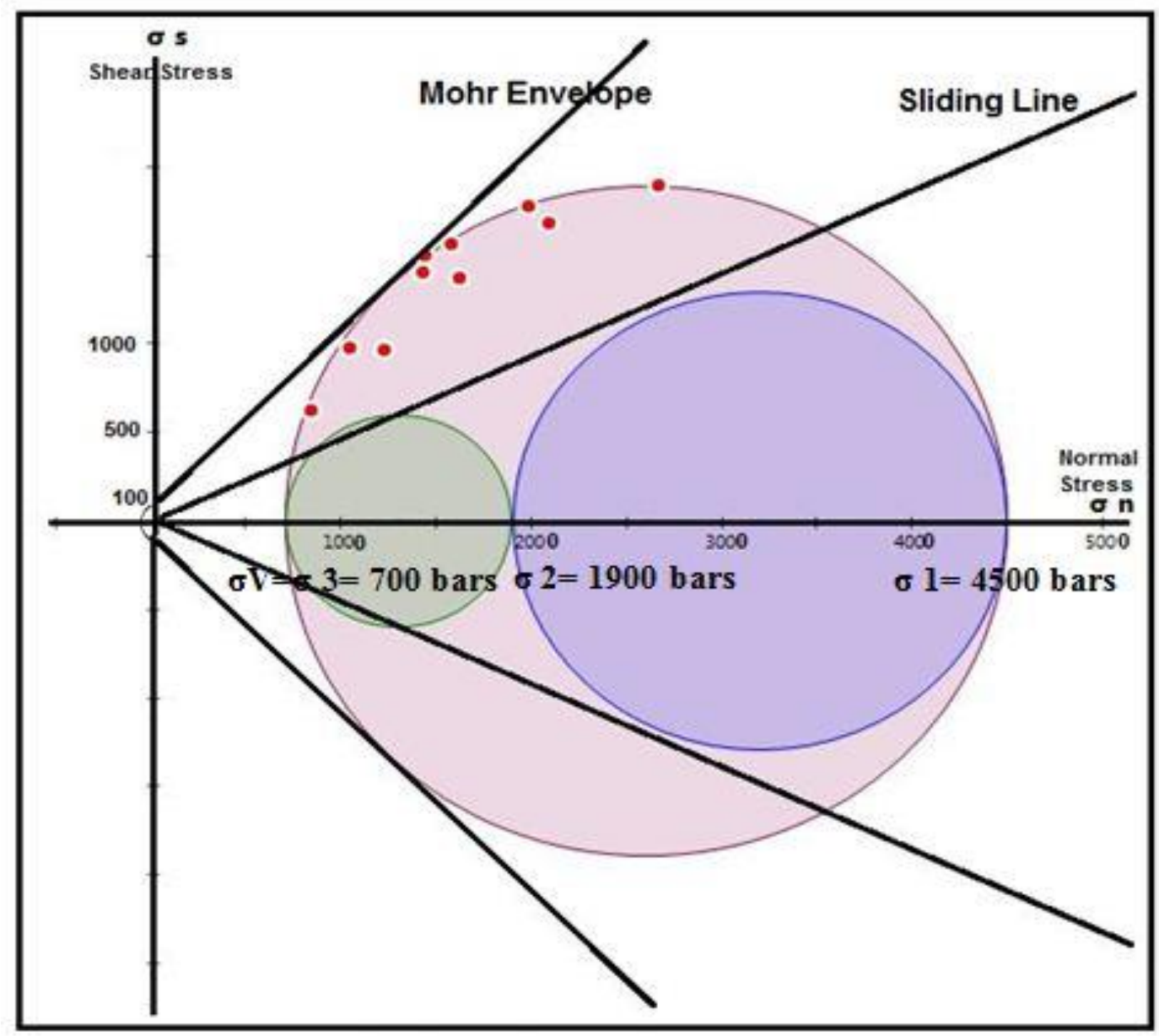

(b)

Figure 5- Mohr Circles to calculate the magnitudes of the principal stresses in the study area. (a) The friction sliding line $35^{\circ}$. (b) The friction sliding line $25^{\circ}$.

Table 2- The magnitudes of the principal stress axes $(\sigma 1, \sigma 2, \sigma 3)$ of the study area.

\begin{tabular}{|c|c|c|c|c|c|c|c|c|}
\hline $\begin{array}{c}\sigma 1 \\
\text { bar }\end{array}$ & $\sigma 2$ bar & $\begin{array}{l}\sigma 3=\sigma \\
\mathbf{v} \text { bar }\end{array}$ & $\begin{array}{c}\text { Depth } \\
\text { (m). }\end{array}$ & $\begin{array}{c}\text { Density } \\
\mathrm{Kg} / \mathrm{m}^{3}\end{array}$ & $\begin{array}{c}\text { Hydrostatic } \\
\text { Pressure bar } \\
= \\
(\sigma 1+\sigma 2+\sigma \\
3) / 3\end{array}$ & $\begin{array}{l}\text { Cohesion } \\
\text { Strength } \\
= \\
\left(\begin{array}{c}\sigma 1-\sigma \\
\text { bar }\end{array}\right) \\
\quad\end{array}$ & $\begin{array}{l}\text { d2 bar } \\
(\sigma 1-\sigma 2)\end{array}$ & $\begin{array}{l}\text { d1 bar }= \\
(\sigma 2-\sigma 3)\end{array}$ \\
\hline 4500 & 1900 & 700 & 5072 & 2300 & 2366.6 & 3800 & 2600 & 1200 \\
\hline
\end{tabular}

Thrust faulting in Bekhme structure involved a compression regime with $(\sigma 1)$, which was almost horizontal in the NE-SW trend, approximately perpendicular to the direction of Bekhme structure axis The extensional axis $(\sigma 3)$ was sub vertical and the intermediate axis $(\sigma 2)$ was horizontal in the NW-SE trend, approximately parallel to the direction of Bekhme structure axis, as shown in Figure -6. 


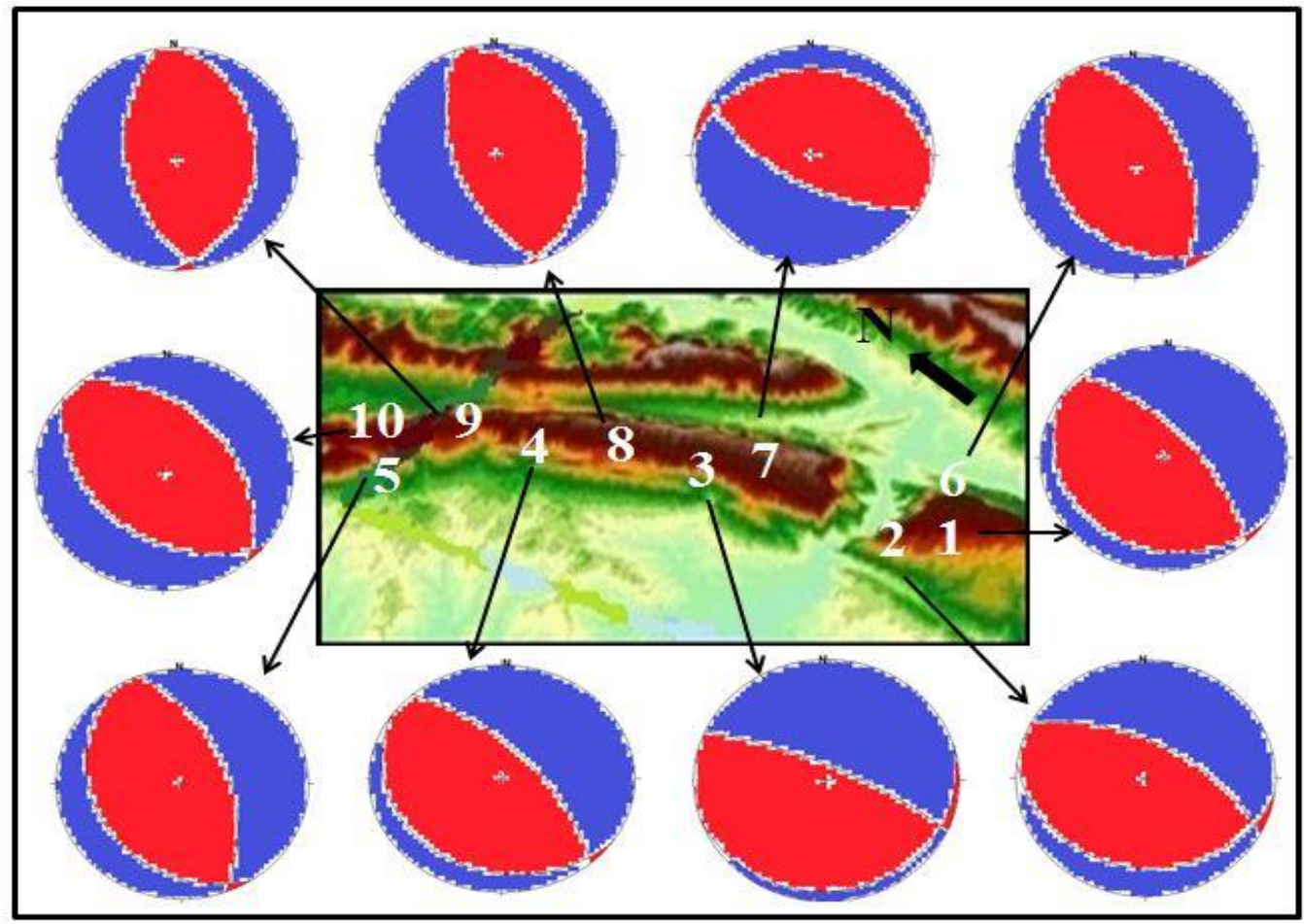

Figure 6- According to the study of faults solution in the lower hemisphere equal- area projection, the red color is an extensional field which contains $(\sigma 3)$ and the blue color is a contractional field which contains $(\sigma 1)$.

\section{Discussion}

The sedimentary rocks of the Mesozoic -Cenozoic Era (Sargalu and Bai- Hassan Formations) were studied to analyze the paleostresses based on fault slip data field analysis, Right dihedral method, Mohr circles, Bott equation, and Lisle graph. Mohr diagram showed that the poles of the thrust faults lie between the sliding lines and the failure envelope. It is clear that the poles of the fault planes were found by Mohr diagram to be associated with relatively low shear stress and high normal stress. This indicates that these faults do not have to slip under these conditions. However, the reality is opposite to this, due to the fact that the movement of these faults has already taken place. This contradiction may be due to several reasons. First, The effects of pore-fluid pressure, which reduces the magnitudes of the normal effective stresses, has not been taken into account, or there could be some error in the overburden thickness estimates. Second, the uplifting of the rock beds may change their orientations at a later stage.

The study results showed that the orientation axes of principal stress and their magnitudes are sufficient to reactivate faults. Magnitudes of the stress were not constant, and the stress ellipsoid was different. This difference may be due to the difference of the stress fields, the depth variation, and the possibility that the stress magnitudes were changed with time. The high magnitudes of the normal stresses may refer to the active tectonic events which led to the deformation of the area during the Mesozoic and Cenozoic Eras.

\section{Conclusions}

The style of the structural units in the Mesozoic and Cenozoic Eras is complex and appears to be controlled by a variation of mechanical stratigraphic units across Zagros Fold Thrust Belt. Magnitudes of the principal stresses were calculated depending on rupture- friction law and the known depth of burial. The maximum principal stress $(\sigma 1)$ was found to be (4500) bars, the intermediate principal stress $(\sigma 2)$ was (1900) bars, and the minimum principal stress $(\sigma 3)$ was (700) bars.These stress magnitudes are sufficient to produce reactivation in faults in the studied area. The study area is located within the unstable region, since the poles of the measured faults lie in the area of the faults reactivation in Mohr diagram. The stress ratio magnitudes on Lisle graph show mean values in the order of $(R=0.5)$, which indicates that the state of the stress was flattening $(\sigma 1>\sigma 2>\sigma 3)$. The studied area was affected by a compression stress system during the Alpine Orogeny compression. 


\section{References}

1. Al- Obaidi, M. R., 1978. A Study of Geological Structures of Jabel Sinjar, M.S. Thesis, University of Baghdad, Baghdad, Iraq.238p.

2. Al-Obaidi, M. R., 1994. Stress field determination (Orientation and Magnitudes) and their relation to structural trends and overburden thickness for Sinjar and Bashiqa structures, North of Iraq, Journal of Science. Iraq. 35(2):365- 380.

3. Handula, R. E., 1997. Structural and stress analysis in the folded area north and northeast of Iraq, M.S. thesis, University of Baghdad, Baghdad, Iraq.127p.

4. Al- Diabat, A. A., Al-Obaidi, M. R., and Atalla M., 2003. Magnitudes of the Paleostresses at the Eastern Rim of the Dead Sea Transform Fault”, Journal of Pure Sciences, 30(1): 1-13.

5. Al- Hachem, A. E., 2018. The Structural and Tectonic Analysis of Missan area Southeastern part of Iraq, Ph. D. Thesis. University of Baghdad, Baghdad, Iraq, 205p.

6. Abdulhassan, A. K., 2019. Paleostress Analysis of Selected Structures in Southeastern Part of Low Folded Zone/ IRAQ, Ph. D. Thesis. University of Baghdad, Baghdad, Iraq. 211p.

7. Al-Jumaily, I . S., Adeed, H. G., Al- Hamdani, R. K. and Dawlat, M. S., 2012. Structural Analysis and Tectonic Interpretation of Brittle Failure Structures at Perat Anticline-NE Iraq. Iraqi National Journal of Earth Science, 12(2): 17-42.

8. Kaymaki, N., 2006. Kinematic development and paleostress analysis of the Denizli Basin western Turkey, Journal of Asia Earth Sciences, 27: 207-222.

9. http:// www. Google earth image, 2019.

10. Al- Khadimi, J. A., Sissakian, V. K., Fattah , A. S., and Deikaran, D. B.,1996. Tectonic map of Iraq, (Scale: 1:1 000000) S. E. of Geological Survey and Mining, Iraq.

11. Numan, N.M., 1997. A plate tectonic scenario for the Phanerozoi succession in Iraq. Jour. Geol. Soc. Iraq, 30(2): 85-110.

12. Jassim, S. Z., and Goff, J. C. 2006. Geology of Iraq. Published by Dolin, Prague Moravian Museum, Brno, Czech Republic.

13. Shihab, A. T., 2015. Structural Analysis Using Remote Sensing and GIS Techniques in the High Folded Zone between Harir and Bradost Anticlines, Northeast Iraq, M.S. Thesis, University of Baghdad, Baghdad, Iraq.174p.

14. Al-Hachem, A. E., and Al - Obaidi, M. R., 2018. Determination of the Paleostress Orientations and Magnitudes for Missan Structures, Southeastern Iraq. Journal of University of Babylon for Pure and Applied Sciences, 26(10): 213-223.

15. Abdualhassan, A. K., and Al-Obaidi, M. R., 2018. Determination of the Paleostress Magnitudes of the Eastern Part of the Low Folded Zone, E- Iraq , Indian Journal of Natural Sciences, 9 (50): 15145-15152.

16. GEOrient ver. $9.5,2011$.

17. Sassi, W. and Carey - Gailhardis, E. 1987. Interpretation mechanique du glissementsur les failles: Introduction dun critere de frottement “, Annales Tectonicae, 1: 139- 154.

18. Suppe, J., 1985. Principle of structural geology. Prentile- Hall, Inc. Engle wood cliffs, New Jersey.

19. Fossen, H., 2012. Structural Geology: United States of America, Cambridge University Press, third edition. 463p.

20. Bott, M. H., 1959. The mechanics of oblique slip faulting, Geol. Mag., 96: 109-117.

21. Lisle, J., 1979. The representation and calculation of the deviatoric component of the Geological stress tenser. Journal of Structural Geology, 1: 317-321.

22. Al- Obaidi, M. R. and Al-Kotbah, A. M. 2003. The magnitudes of the paleostresses of Yemen Faults in the sedimentary cover. Faculty of Science Bulletin, 16: 95-109.

23. Al- Banna, A. S., and Ali, K. K., 2018. The Transform Tectonic Zone between Two Parts of the Platform in Iraq: a Review Study. Iraqi Journal of Science, 59(2C): 1086-1092.

24. Al- Banna, A.S. and Al-Kishef, D.s. 2019. Evalution of the Tectonic Boundaries in Tikrit- Kirkuk Area Using Potential Data, North- Central Iraq. Iraqi Journal of Science, 60(3): 528-535.

25. Al Banna, A.S. and Al-Namar, A.F., 2019. Gravity and Magnetic Interpretation of Study Deep Crustal Structures in Karbala and Surrounding Areas- Central Iraq. Iraqi journal of Science, 69(3): 536-544. 